J Venom Anim Toxins incl Trop Dis, 2019 25: e148218

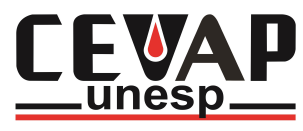

\author{
The Journal of Venomous Animals and \\ Toxins including Tropical Diseases \\ ISSN 1678-9199 \\ Journal homepage www.jvat.org
}

\title{
Proteome of fraction from Tityus serrulatus venom reveals new enzymes and toxins
}

\author{
Fernanda Gobbi Amorim ${ }^{1,2}$, Heloisa Tavoni Longhim ${ }^{1}$, Camila Takeno Cologna ${ }^{1,3}$, Michel Degueldre ${ }^{3}$, \\ Edwin De Pauw³, Loïc Quinton³, Eliane Candiani Arantes,** (D) \\ ${ }^{1}$ Department of Physics and Chemistry, School of Pharmaceutical Sciences of Ribeirão Preto, University of São Paulo, Av. do Café s/n, Monte Alegre, \\ Ribeirão Preto, SP 14040-903, Brazil. \\ ${ }^{2}$ University of Vila Velha, Vila Velha, ES, Brazil. \\ ${ }^{3}$ Laboratory of mass spectrometry, MolSys Research Unit, Liège Université, Liège, Belgium.
}

\section{Article Info Keywords: \\ Tityus serrulatus \\ scorpion venom \\ enzymes \\ proteases}

ACE inhibitors

proteome

\begin{abstract}
Background: Tityus serrulatus venom (Ts venom) is a complex mixture of several compounds with biotechnological and therapeutical potentials, which highlights the importance of the identification and characterization of these components. Although a considerable number of studies have been dedicated to the characterization of this complex cocktail, there is still a limitation of knowledge concerning its venom composition. Most of $T s$ venom studies aim to isolate and characterize their neurotoxins, which are small, basic proteins and are eluted with high buffer concentrations on cation exchange chromatography. The first and largest fraction from carboxymethyl cellulose-52 (CMC-52) chromatography of Ts venom, named fraction I (Fr I), is a mixture of proteins of high and low molecular masses, which do not interact with the cation exchange resin, being therefore a probable source of components still unknown of this venom. Thus, the present study aimed to perform the proteome study of Fraction I from Ts venom, by high resolution mass spectrometry, and its biochemical characterization, by the determination of several enzymatic activities.

Methods: Fraction I was obtained by a cation exchange chromatography using $50 \mathrm{mg}$ of crude venom. This fraction was subjected to a biochemical characterization, including determination of L-amino acid oxidase, phospholipase, hyaluronidase, proteases activities and inhibition of angiotensin converting enzyme (ACE) activity. Fraction I was submitted to reduction, alkylation and digestion processes, and the tryptic digested peptides obtained were analyzed in a Q-Exactive Orbitrap mass spectrometer. Data analysis was performed by PEAKS 8.5 software against NCBI database.

Results: Fraction I exhibits proteolytic activity and it was able to inhibit ACE activity. Its proteome analysis identified 8 different classes of venom components, among them: neurotoxins (48\%), metalloproteinases (21\%), hypotensive peptides (11\%), cysteine-rich venom protein (9\%), antimicrobial peptides (AMP), phospholipases and other enzymes (chymotrypsin and lysozymes) (3\%) and phosphodiesterases (2\%).
\end{abstract}

\footnotetext{
* Correspondence: 
Conclusions: The combination of a proteomic and biochemical characterization strategies leads us to identify new components in the T. serrulatus scorpion venom. The proteome of venom's fraction can provide valuable direction in the obtainment of components in their native forms in order to perform a preliminary characterization and, consequently, to promote advances in biological discoveries in toxinology.

\section{Background}

Scorpion venoms are a rich source of components with diverse biological activities and high specificity for their targets [1]. Their venoms are usually composed of insoluble mucus, oligopeptides, mucopolysaccharides, nucleotides, low molecular weight molecules (serotonin or histamine), protease inhibitors, histamine releasers, amino acids and other organic compounds, enzymes and many neurotoxins [2-4]. Among this impressive cocktail, neurotoxins are the main components studied, mostly because of their interaction with $\mathrm{Na}^{+}$or $\mathrm{K}^{+}$channels and their importance in the scorpion envenoming [5]. In addition, several enzymes have been characterized in scorpion venoms, including phospholipase A, hyaluronidase, sphingomyelinase $\mathrm{D}$, lysozyme, metalloproteases and serine proteases. Other enzymes have been related with the post-translational processing of toxin precursors and with the facilitation of venom permeation into tissues $[3,6]$.

The study of venom components is highly useful for elucidating the biochemical process of envenoming, but also for identifying molecules that can be used as molecular tools and/or drugs with therapeutic action. So far, the number of distinct toxins present in scorpion venoms has been estimated at about 100.000, and only less than $1 \%$ has been characterized $[7,8]$.

The initial fractionation of Tityus serrulatus (Ts) venom on a carboxymethyl cellulose-52 (CMC-52) column, described by Arantes et al. [9] and modified by Cerni et al. [5], uses ammonium bicarbonate buffer, $\mathrm{pH} 7.8$, and allows separate $T s$ venom components in 18 fractions, according to their charge. The positively charged proteins at this $\mathrm{pH}$ (such as neurotoxins) interact with the cation exchange resin and the other proteins are eluted in the first fractions of the chromatography. Fraction I (Fr I) is the first and largest peak eluted on CMC-52 chromatography and was never in depth studied before. It is composed by a mixture of proteins of high and low molecular masses, being a probable source of components still unknown of T. serrulatus venom and, therefore, was chosen to be analyzed in this study [9].

Proteomic techniques have been employed to explore the diversity of toxins present in scorpion venom. Protein separation techniques, such as high performance liquid chromatography (HPLC) hyphened with soft ionization mass spectrometers, allowed a more detailed proteomic analysis of animal venoms $[1,10-18]$. Those techniques provide a broad range of structural information such as the amino acid sequence for peptides, accurate determination of molecular mass, determination of disulfide bonds, and characterization of post-translational modifications [19]. Furthermore coupled techniques such as chromatography and electrospray ionization (ESI) permit mass spectrometry to become the method of choice for the analysis of complex mixtures such as animal venoms [20].
With the advent of omics techniques, studies of animal venoms have become increasingly faster and more comprehensive, often able to provide a holistic view of all components in the venom specially when combined to Next Generation Sequencing (NGS) transcriptomics [21]. Therefore, due the high complexity of scorpion venoms, a proteome fraction-directed or fraction subproteomes combined to shotgun proteomics can be useful in the identification of new molecules and to guide the obtainment of components in their native forms in order to perform a preliminary characterization. Considering this panorama, the present study carried out a high resolution proteome of Fraction I, the first fraction of the cation exchange chromatography from Tityus serrulatus venom, and its biochemical characterization, aiming the exploration and bioprospection of undiscovered components.

\section{Methods \\ Venom Fractionation}

Ts venom was obtained from the vivarium of the Faculdade de Medicina de Ribeirão Preto da Universidade de São Paulo (School of Medicine of Ribeirão Preto, University of São Paulo, Brazil), using electrical stimulation of $12 \mathrm{mV}$. The freeze-dried venom was diluted in ultra pure water (MilliQ $)$ and desiccated for 6 h. After this procedure, the sample $(50 \mathrm{mg})$ was resuspended in $500 \mu \mathrm{L}$ of $50 \mathrm{mM}$ ammonium bicarbonate buffer, $\mathrm{pH} 7.8$, and centrifuged at $13,000 \mathrm{rpm}$ for $10 \mathrm{~min}$ at $4{ }^{\circ} \mathrm{C}$ (Centrifuge 5415 $\mathrm{R})$. Ammonium bicarbonate buffer $(500 \mu \mathrm{L})$ was added to the precipitate, the mixture was homogenized and centrifuged. This process was repeated twice. The supernatants from the 4 extractions (final volume of $2.0 \mathrm{~mL}$ ) were pooled, held at $4{ }^{\circ} \mathrm{C}$ for 12 hours, and centrifuged at 13,000 rpm for 10 minutes. At the end of this process, the soluble venom (without mucus) was submitted to a fast protein liquid chromatography (FPLC), using a CMC-52 microgranular column 1.6 x $100 \mathrm{~cm}$ (Whatman, UK), equilibrated with buffer A (50 $\mathrm{mM}$ ammonium bicarbonate, $\mathrm{pH}$ 7.8), as described by Cerni et al. [5]. The sample (2 mL) was initially eluted with buffer $\mathrm{A}$, followed by a linear concentration gradient ( 0 to $100 \%)$ of buffer $\mathrm{B}(0.6 \mathrm{M}$ ammonium bicarbonate, $\mathrm{pH} 7.8$ ), under a flow rate of $0.5 \mathrm{~mL} / \mathrm{min}$ and temperature of $25^{\circ} \mathrm{C}$. Absorbance was automatically recorded at $280 \mathrm{~nm}$. All the fractions obtained were lyophilized and stored at $-20^{\circ} \mathrm{C}$.

\section{Eletrophoresis}

The fractions obtained from the venom chromatography were analyzed by tricine sodium dodecyl sulfate polyacrylamide gel electrophoresis (Tricine-SDS-PAGE) following the method used for ultra-low mass proteins [22]. It was used a $16.5 \%$ separating gel, overlaid by a $5 \%$ stacking gel. The gels were stained with 
PlusOne Coomassie Blue PhastGel R-350 (GE Healthcare, UK) and destained with $10 \%$ acetic acid (v/v). The ultra-low range molecular weight marker (Sigma-Aldrich Co., USA) was used.

\section{Biochemical characterization Phospholipase activity}

Phospholipase activity was assessed in Petri dishes [23], with the following modifications: agarose was replaced by agar and erythrocytes were not used. Briefly, a gel containing $0.01 \mathrm{M}$ $\mathrm{CaCl}_{2}$, egg yolk diluted in phosphate-buffered saline (PBS) at pH 7.2 in the ratio $1: 3(\mathrm{v} / \mathrm{v}), 1 \%$ bacteriological agar, and $0.005 \%$ sodium azide was prepared in Petri dishes. Then, $40 \mu \mathrm{L}$ of the fraction was applied into $5-\mathrm{mm}$ diameter holes made in the gel, followed by incubation at $37{ }^{\circ} \mathrm{C}$ overnight. The formation of translucent halos around the holes in the gel indicated phospholipase activity.

\section{Proteolytic activity on azocasein}

The azocaseinolytic activity was determined by colorimetric assay [24], in which $85 \mu \mathrm{L}$ of an azocasein solution $(5 \mathrm{mg} / \mathrm{mL}$ in $50 \mathrm{mM}$ Tris- $\mathrm{HCl} \mathrm{pH} \mathrm{8.0)} \mathrm{were} \mathrm{incubated} \mathrm{with} 10 \mu \mathrm{L}$ of venom fraction (Fraction I: $47 \mu \mathrm{g} / \mu \mathrm{L}$ ) in $50 \mathrm{mM}$ Tris- $\mathrm{HCl}, \mathrm{pH} 8$, and $5 \mu \mathrm{L}$ of solution of $100 \mathrm{mM}$ protease inhibitors (phenylmethylsulfonyl fluoride, PMSF and ethylenediamine tetraacetic acid, EDTA), for 90 minutes at $37^{\circ} \mathrm{C}$. Next, $200 \mu \mathrm{L}$ of $5 \%$ trichloroacetic acid (TCA) (v/v) was added to the samples followed by centrifugation at $1000 \mathrm{x} g$ for 5 minutes. Then, $150 \mu \mathrm{L}$ of $0.5 \mathrm{M} \mathrm{NaOH}$ were added to the supernatants and read at $450 \mathrm{~nm}$.

\section{L-amino acid (LAAO) activity}

LAAO activity was detected spectrophotometrically according to Kishimoto and Takahashi [25]. Each venom fraction was incubated with $2 \mathrm{mM} o$-phenylenediamine (Sigma-Aldrich Co., USA), $1 \mathrm{U} / \mathrm{mL}$ horseradish peroxidase (Sigma-Aldrich Co., USA), 5 mM L-leucine (Sigma-Aldrich Co., USA), and $0.05 \mathrm{M}$ Tris- $\mathrm{HCl}$ buffer, $\mathrm{pH}$ 7.0. Incubation was performed at $37^{\circ} \mathrm{C}$ for 1 hour and then the reaction was quenched with $2 \mathrm{M}$ $\mathrm{H}_{2} \mathrm{SO}_{4}$. The absorbance was determined on a microplate reader at wavelength of $492 \mathrm{~nm}$, with reference to absorbance at 630 $\mathrm{nm}$. To determine the amount of $\mathrm{H}_{2} \mathrm{O}_{2}$ released, a calibration curve was made with $\mathrm{H}_{2} \mathrm{O}_{2}(0-10 \mathrm{mM})$. According to Kishimoto and Takahashi [25], 1 unit of LAAO activity is defined as the amount of enzyme required to produce $1 \mu \mathrm{mol}$ of $\mathrm{H}_{2} \mathrm{O}_{2}$ per minute under the specified conditions.

\section{Angiotensin Converting Enzyme (ACE) inhibitory activity}

ACE inhibitory activity in vitro was evaluated following the procedures described by Li et al. (2005) and modified by Pinheiro-Júnior (2018) to miniaturize the methodology to $2 \mathrm{~mL}$ micro tubes $[26,27]$. The mixture of $30 \mu \mathrm{L}$ of $5 \mathrm{mM}$ Hippuryl-HisLeu (HHL, Sigma-Aldrich Co., USA) in $100 \mathrm{mM}$ borate buffer, pH 8.3 (Sigma-Aldrich Co., USA), containing $300 \mathrm{mM} \mathrm{NaCl}$, was incubated for $5 \mathrm{~min}$, at $37^{\circ} \mathrm{C}$, with $20 \mu \mathrm{L}$ of each venom fraction solution. As negative control of inhibition (100\% ACE activity), $20 \mu \mathrm{L}$ of the same buffer was used. ACE $(20 \mu \mathrm{L}$ of 100 $\mathrm{mU} / \mathrm{mL}$ solution; Sigma-Aldrich Co., USA) was later added to the mixture, which was then incubated for $2 \mathrm{~h}$, at $37^{\circ} \mathrm{C}$. The reaction was stopped with addition of $20 \mu \mathrm{L}$ of $\mathrm{HCl} 2 \mathrm{~N}$. The hippuric acid (HA), formed during ACE catalysis, was quantified by the incubation with $120 \mu \mathrm{L}$ of quinoline (Sigma-Aldrich Co., USA) and $40 \mu \mathrm{L}$ of benzenesulfonyl chloride (BSC, SigmaAldrich Co., USA) for $30 \mathrm{~min}$, at $30^{\circ} \mathrm{C}$. The chromogen formed by HAquinoline-BSC was diluted with $250 \mu \mathrm{L}$ of ethanol, followed by another incubation, under the same conditions. Then, 290 $\mu \mathrm{L}$ of the mixture was transferred to a 96 -well plate and the absorbance was measured at $492 \mathrm{~nm}$ in a microplate absorbance reader (Sunrise Basic TECAN, Austria). The percentage of ACE inhibitory activity was calculated by the multiplication by 100 of the difference from the absorbance in the reaction without and with inhibitor divided by the difference of absorbance in the reaction without inhibitor and negative control. All the experiments were performed in triplicate.

\section{Hyaluronidase activity}

Hyaluronidase activity was quantitatively determined by the turbidimetric assay as described by Pukrittayakamee et al. [28], adapted to a 96-well microplate and under conditions described by Amorim et al. [29]. For this assay it was used acetate buffer (200 mM sodium acetate and $150 \mathrm{mM} \mathrm{NaCl} \mathrm{pH} \mathrm{6.0),} 10 \mu \mathrm{g}$ hyaluronan $(0.5 \mathrm{mg} / \mathrm{mL}$ in water $)$ and the fraction I to the final volume of $200 \mu \mathrm{L}$. The mixture was incubated for $30 \mathrm{~min}$ at 37 ${ }^{\circ} \mathrm{C}$, and the reaction was stopped with the addition of $100 \mu \mathrm{L}$ of $5 \%$ cetyltrimethylammonium bromide (CTAB) and $4 \% \mathrm{NaOH}$ $(\mathrm{w} / \mathrm{v})$. Then, the absorbance of the mixture was read at 400 $\mathrm{nm}$ in a microplate reader (Sunrise Basic, Tecan, Switzerland). Hyaluronidase activity was expressed as the percentage of hydrolyzed hyaluronan, considering the absorbance of the tube in which no hyaluronan was added as $100 \%$ of hydrolysis.

\section{Inhibition/potentiation of trypsin and chymotrypsin activity}

A possible inhibitor or enhancer of trypsin/chymotrypsin activity present in venom fraction was tested. The reaction mixture was prepared as described by the supplier (PBS, enzyme, venom and chromogenic substrate specific for each enzyme). The assay was performed with bovine trypsin and a-chymotrypsin (1 $\mathrm{mg} / 50 \mathrm{~mL}, 0.001 \mathrm{M} \mathrm{HCl}$; Sigma-Aldrich Co., USA), trypsin and $\alpha$-chymotrypsin substrates $(10 \mathrm{mg} / \mathrm{mL} \mathrm{N}$-p-Tosyl-Gly-Pro-Lys4-nitroanilide acetate salt and $0.2 \mathrm{mg} / \mathrm{mL} \mathrm{N}$-Succinyl-Ala-AlaPro-Phe-p-nitroanilide, respectively; Sigma-Aldrich Co., USA), phosphate-buffered saline (PBS) $\mathrm{pH}$ 7.4, and Fraction I at two concentrations $(1.90 \mathrm{mg} / \mathrm{mL}$ and $5.65 \mathrm{mg} / \mathrm{mL})$. The substrate solution was prepared at the $1 \mathrm{mg} / 20 \mathrm{~mL}$ assay concentration in PBS. Volumes of $5 \mu \mathrm{L}$ of bovine trypsin and a-chymotrypsin were tested with $5 \mu \mathrm{L}$ of substrate in the 96 -well samples at room 
temperature with $100 \mu \mathrm{L}$ PBS. The reaction mixtures were read at $410 \mathrm{~nm}$ to quantify the formation of p-nitroaniline (yellowish color) every 2 minutes during 200 minutes.

\section{Statistical Analyses}

Experimental data are presented as mean \pm SD, and they were analyzed with the GraphPad Prism software, version 6.0 for Windows (GraphPad Software, La Jolla, USA, 2012), using Student's t-test or ANOVA followed by Sidak post-hoc. Values of $\mathrm{p}<0.05$ were considered statistically significant.

\section{Proteomics analysis \\ In solution digestion of Fraction I}

The lyophilized Fraction I was dispersed with $200 \mu \mathrm{L}$ ultrapure water. The sample remained in the water bath at $37^{\circ} \mathrm{C}$ for 20 minutes and then centrifuged for 5 minutes. The sample was quantified by RC-DC protein assay (Bio-Rad, USA) and the concentration found was $8 \mu \mathrm{g} / \mathrm{mL}$. For reduction of the Fraction I, an aliquot of the lyophilized sample was re-suspended in 8 $\mathrm{mL}$ of $25 \mathrm{mM} \mathrm{NH}_{4} \mathrm{HCO}_{3}$ and $2 \mu \mathrm{L}$ of $100 \mathrm{mM}$ dithiothreitol and incubated for 1 hour at $56^{\circ} \mathrm{C}$ and $300 \mathrm{rpm}$. For further alkylation, $1.5 \mu \mathrm{L}$ of $500 \mathrm{mM}$ iodoacetamide was added to the sample and incubated in the dark for 1 hour at room temperature. Then, the fraction sample was digested by trypsin in $50 \mathrm{mM}$ $\mathrm{NH}_{4} \mathrm{HCO}_{3}, \mathrm{pH} 7.8$, in a ratio of 1:50 and incubated overnight, at $37^{\circ} \mathrm{C}$, under shaking at $300 \mathrm{rpm}$. Reaction was stopped by adding $10 \%$ TFA (v/v) to the reaction mixture, and the sample was dried on speed vacuum. Sample was suspended in $20 \mu \mathrm{L}$ of 0.1\% TFA (v/v) for desalting on ZipTip ${ }^{\mathrm{TM}}$ pipette tips with C18 resin (Millipore, Darmstadt, Germany), using an acetonitrile/ water/TFA (49.8/50/0.2 v/v) solution as eluent.

\section{Shotgun proteomics}

For shotgun proteomics analysis, the digested material was analyzed in the Acquity UPLC ${ }^{\circ} \mathrm{M}$-Class (Waters, Milford, MA, USA) coupled to the Q-Exactive Orbitrap ${ }^{\mathrm{TM}}$ Mass Spectrometer (Thermo Scientific, Bremen, Germany). The chromatographic system is equipped with a $100 \mu \mathrm{m}$ x $25 \mathrm{~cm}$ monolithic PepSwift capillary column (Thermo Scientific, Waltham, MA, USA). The elution of the peptides was performed with a gradient of 3-50\% solution B in 80 minutes (A: $\mathrm{H} 2 \mathrm{O} / 0.1 \%$ FA; B: acetonitrile) in a flow rate of $0.7 \mathrm{~mL} / \mathrm{min}$.

\section{Data analysis}

Raw data was loaded into Peaks 8.5 software (Bioinformatics solutions, Waterloo, Canada) [30] with database created by the deposits with "Scorpion" keyword from NCBI database downloaded in June 2018 (42,656 sequences). Carbamidomethylation was set as fixed modification, while oxidation (M) and amidation were set as variable modifications. The maximum missed cleavages were set at 3 for trypsin. Parent mass and fragment mass error tolerance were fixed at $5 \mathrm{ppm}$ and $0.015 \mathrm{Da}$, respectively. False discovery rate (FDR) of $1 \%$ and unique peptide $\geq 2$ were used for filtering out inaccurate proteins for the SPIDER search. Only peptides with $-10 \lg P>20$ were used to detect the proteins from the database. The percentage of the venom components in the Fraction I was calculated over the total proteins detected using LC - MS/MS [31].

\section{Results}

\section{Biochemical characterization}

Ts venom was fractioned using a cation exchange column CMC52, resulting in 18 fractions (Fig. 1A). Fraction I is the first to be eluted during the chromatography and represents around $30 \%$ of the soluble venom. According to the electrophoresis gel it is possible to observe that this fraction is rich on a wide range of molecular mass components (Fig. 1B).

Fraction I was subjected to different assays for the identification of proteases (serine proteases, metalloproteinases), L-amino acid oxidases, hyaluronidases and bradykinin potentiating peptides. Fraction I did not demonstrated phospholipase, hyaluronidase or LAAO activities (data not shown). However, it exhibits proteolytic activity, as evidenced by increased proteolysis in trypsin and chymotrypsin assays (Fig. 2A) and by the hydrolysis of azocasein substrate (Fig. 2B). The azocasein assay indicates that metalloproteinases (inhibition by EDTA) and serine proteases (inhibition by PMSF) are present in this fraction. In addition, Fraction I was also able to inhibit $77.4 \%$ of the ACE activity (Fig. 2C).

\section{Proteomics}

Mass spectrometry analyses resulted in 4,321 MS and 28,504 MS/MS scans for Fraction I. After applying the parameters described in the Methods section, Fraction I presented 8,017 Peptide Spectrum Matches and 882 peptide sequences that matched the database information. These peptides belong to 66 proteins, among which 56 were identified with more than 2 unique peptides and 10 proteins with 2 unique peptides.

The peptides obtained by high resolution nano-LC-ESIMS/MS were de novo sequenced using the SPIDER algorithm dedicated to the searches into the "Scorpion" database created from NCBI in June 2018. We have considered as an accurate identification just the proteins that matched with at least 2 unique peptides. Therefore, with the de novo sequencing, it was obtained 3,269 mass spectra's, with represented in 95 proteins that matched with the database in the SPIDER section analysis. The full list of proteins and peptides found in this study is reported in Additional file 1.

The results obtained by the biochemical characterization corroborates the proteomics analysis. Among them, $48 \%$ were neurotoxins, $21 \%$ metalloproteinases, $11 \%$ hypotensive peptides and $9 \%$ cysteine-rich venom protein (CRISPs). In this analysis, Fraction I also showed to have antimicrobial peptides (AMPs), phospholipases and other enzymes, such as chymotrypsin and lysozymes, which represents $3 \%$ each of all venom components 


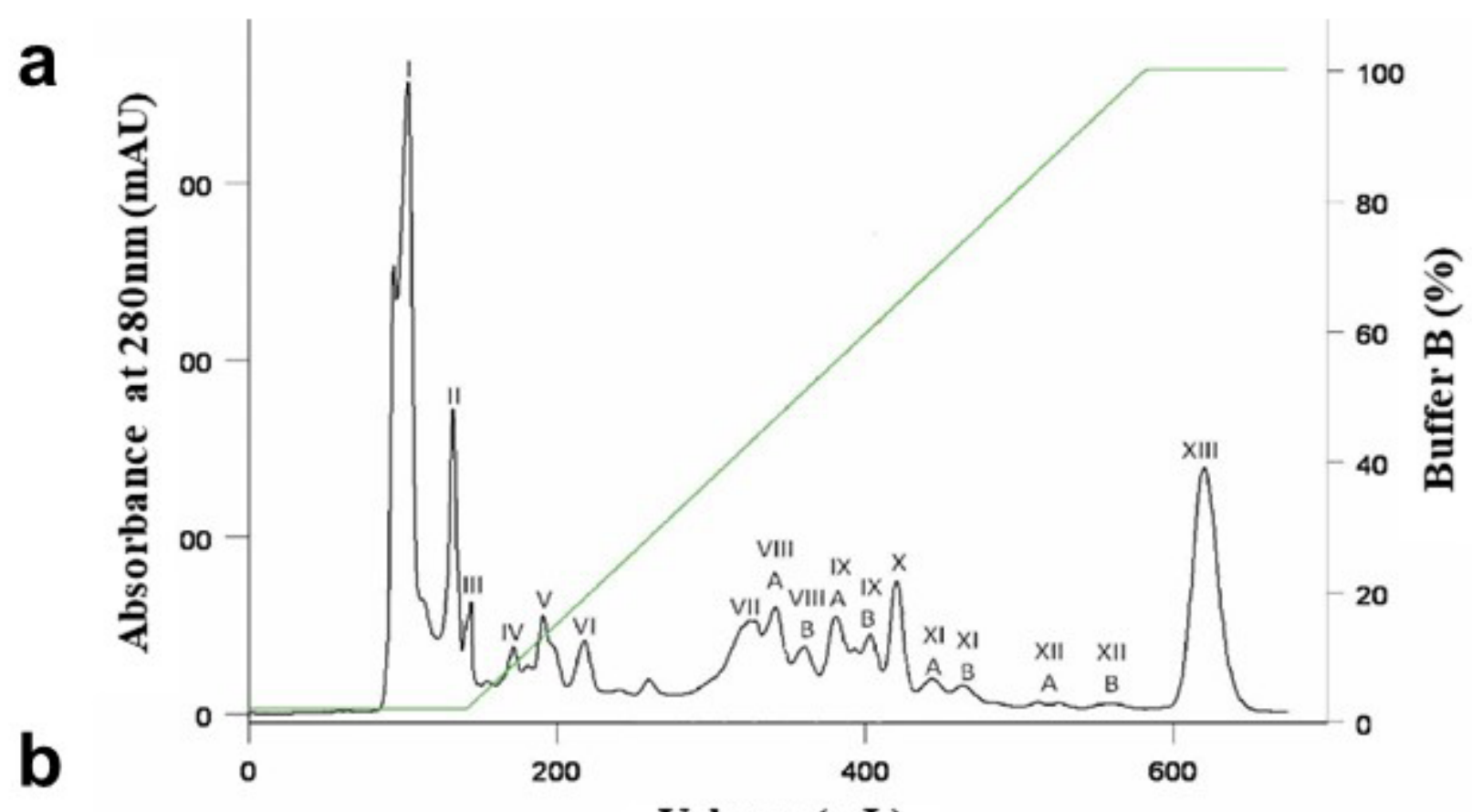

Volume (mL)
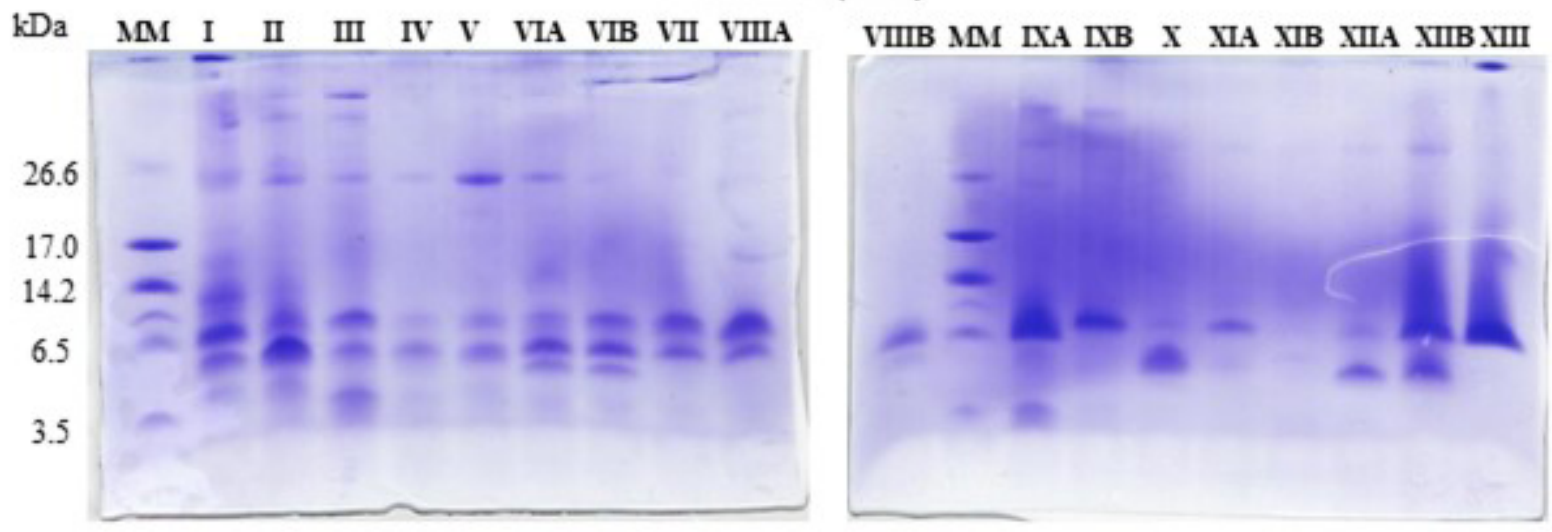

Figure 1. A: Chromatographic profile of Tityus serrulatus venom in FPLC system with CMC-52 column. Fractionation of Ts venom (50 mg) was performed in a FPLC system with CMC-52 column, equilibrated with buffer A (50 mM ammonium bicarbonate, $\mathrm{pH} 7.8$ ), under a flow rate of $0.5 \mathrm{~mL} / \mathrm{min}$ and $25{ }^{\circ} \mathrm{C}$. Sample ( 2 $\mathrm{mL}$ ) was initially eluted with buffer $\mathrm{A}$, followed by a linear concentration gradient ( 0 to $100 \%)$ of buffer $\mathrm{B}(0.6 \mathrm{M}$ ammonium bicarbonate, $\mathrm{pH} 7.8)$, represented by the green line. Volume collected per tube: $4.0 \mathrm{~mL}$. B: Electrophoretic profile of the fractions from the CMC-52 chromatography in $16.5 \%$ Tricine-SDS-PAGE. Gel was stained with PlusOne Coomassie Blue PhastGel ${ }^{\circledR}$ R-350 and destained with $10 \%$ acetic acid (v/v).

identified. In addition, it was identified phosphodiesterases (2\%) in this fraction (Fig. 3).

Fraction I presents several components of high molecular mass, such as enzymes and CRISPs, since it is possible to observe in the electrophoresis gel. The proteomic study identified 8 different venom components classes. De Oliveira et al. [32] described an integration of proteome and transcriptome studies of T. serrulatus and found 14 different classes of venom components, herein we found that 8 of them exist in Fraction I. In addition, it was observed the presence of peptides, such neurotoxins, hypotensive peptides and AMPs, which probably eluted in this fraction aggregated to other venom components. Fraction I is the first to be eluted during the process of fractionation of the venom in a CMC-52 cationic resin, this fact indicates that it is composed of toxins with less basic characters than the others.

Related to ACE inhibition observed in the biochemical analysis, the proteome revealed $11 \%$ hypotensive peptides, including bradykinin-potentiating peptides, hypotensins, PAPE peptides and one endothelin-converting enzyme 1 . The higher coverage of this class was obtained for the Hypotensin-2 (P84190.1), already described by Verano-Braga et al. [33], with 48 peptides sequenced that matched with the 25 amino acids residues from this template. However, the de novo sequencing showed 210 de novo tags for this template, resulted from at least 22 amino acid residues mutations (Additional file 2). Also, 

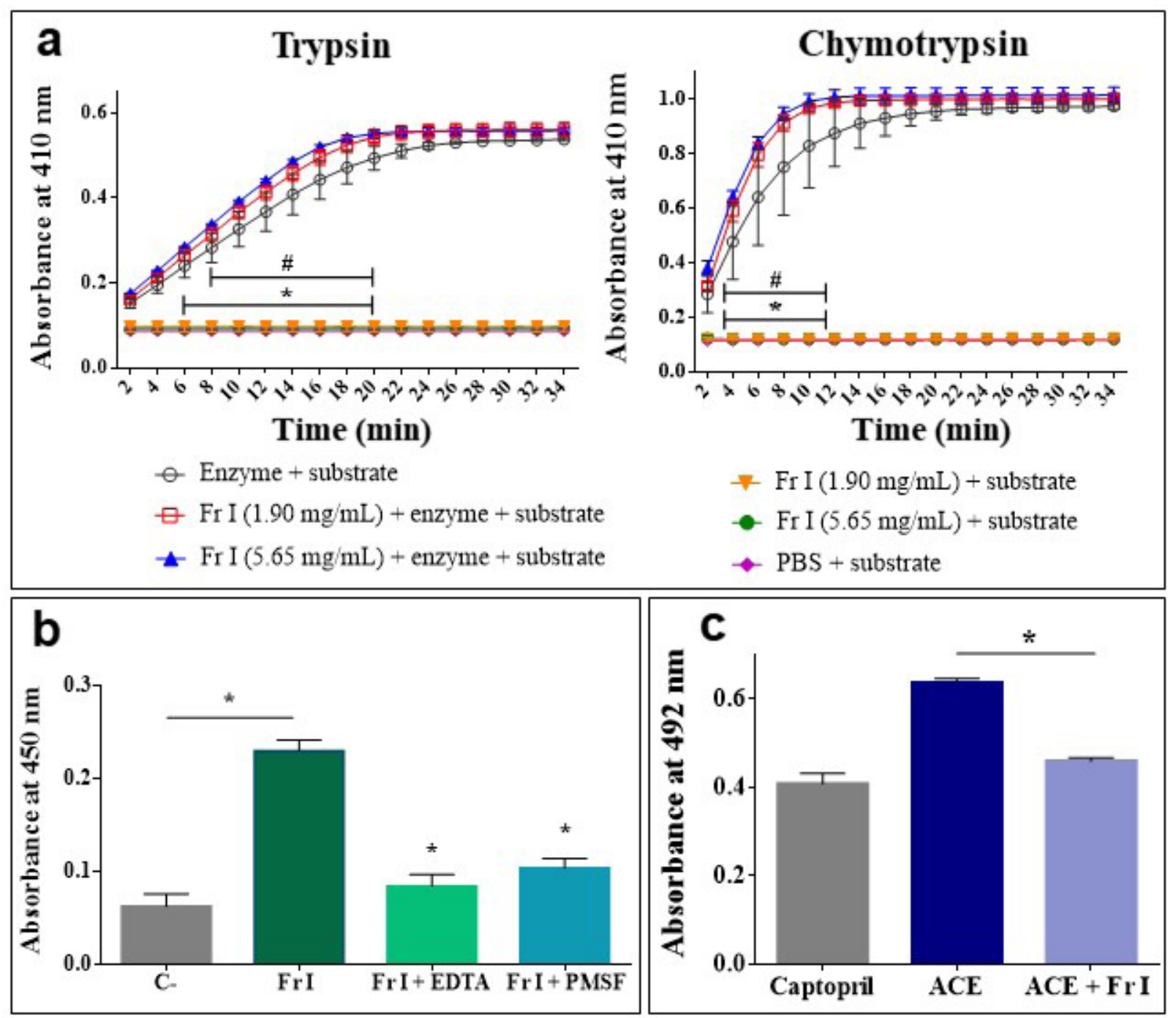

Figure 2. A: Trypsin and chymotrypsin activity assay in the presence of fraction I in two concentrations $(1.90 \mathrm{mg} / \mathrm{mL}$ and $5.65 \mathrm{mg} / \mathrm{mL})$. The absorbance was determined at $410 \mathrm{~nm} .{ }^{*} \mathrm{p}<0.05 \mathrm{Fr}$ I $(5.65 \mathrm{mg} / \mathrm{mL})+$ Trypsin + substrate vs Trypsin + substrate; \#p<0.05 Fr I (1.90 mg/mL) + Trypsin + substrate vs Trypsin + substrate. B: Proteolytic activity of Fraction I (10 $\mu \mathrm{L}, 47 \mu \mathrm{g} / \mu \mathrm{L})$ over azocasein in the absence and presence of inhibitors of metalloprotease (EDTA) and serine protease (PMSF). The absorbance was determined at $450 \mathrm{~nm}$. *p $<0.05 \mathrm{Fr}$ I + EDTA and Fr I + PMSF vs Fr I. C: Inhibition assay of ACE activity by Fraction I $(48.4 \mathrm{mg} / \mathrm{mL})$. Reactions were read at $492 \mathrm{~nm}$. ${ }^{*} \mathrm{p}<0.05 \mathrm{ACE}+\mathrm{Fr}$ I vs ACE. C-: negative control; Fr: Fraction I. Values are expressed as mean \pm SD.

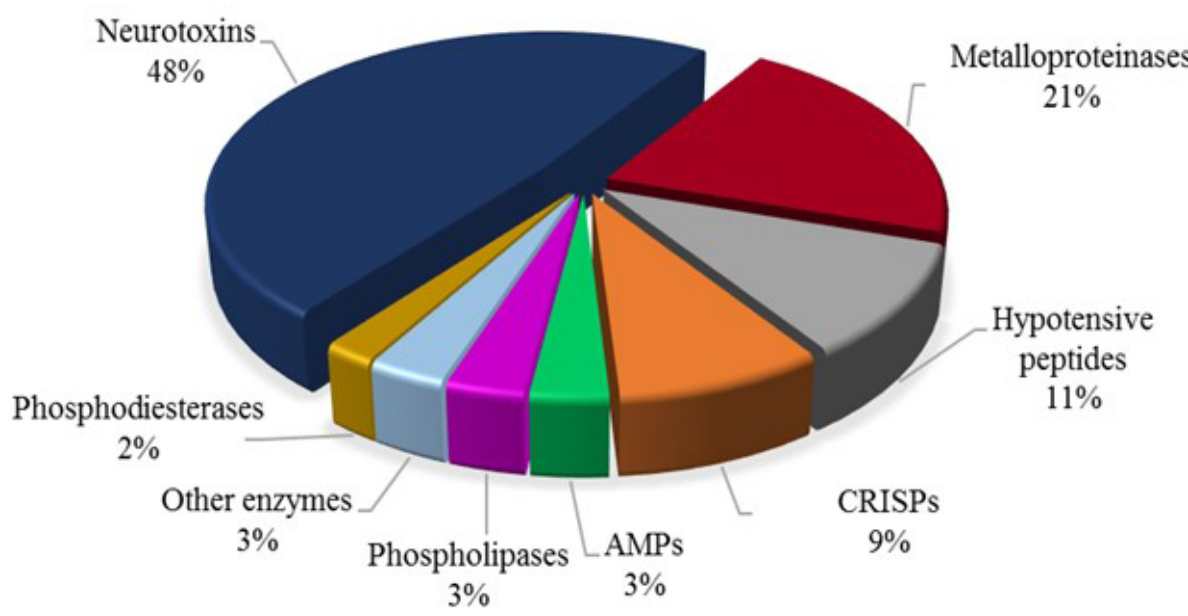

Figure 3. Relative distribution of venom protein classes in Fraction I from Ts venom determined by shotgun-proteomics. AMPs: antimicrobial peptides; CRISPs: cysteine-rich secretory proteins; Other enzymes: lysozyme, chymotrypsin and peptidylglycine alpha-amidating monooxygenase. 
this sequence has 33 possible post-translational modifications, such as the formation of pyro-glutamic ring which hamper the sequencing of these peptides by Edman's Degradation.

In this study, we identified two peptides (YANLGEFPWMVFIR and SELDKNCSGFLLSPSFVLDHK) that matched with a putative venom chymotrypsin-like protease (AG85164.1) from Tityus bahiensis. These findings can explain the enhancing of proteolytic activity of trypsin and chymotrypsin observed in the biochemical analysis of this fraction.

Interesting, the proteome analysis revealed the presence of several CRISPs which were never isolated before and were reported only in the proteomic study of De Oliveira et al. [32]. Herein, we found that this venom component class is eluted in Fraction I, which will be useful in directing the isolation procedure to obtain these toxins. In this study we have covered $57 \%$ of the protein sequence identified by De Oliveira et al [32] (deposit JAW07031.1). This sequence presented 14 posttranslational modifications, including amidations, acetylation, among others (Fig. 4).

The proteome of Fraction I identified venom components classes that were described just in the transcriptome study of De Oliveira et al. [32], such as phospholipases A2, antimicrobial and bradykinin-potentiating peptides. This fact reinforces the importance of a previous fractionation of the venom in order to obtain a more accurate sequencing of the venom components in the proteomics studies.

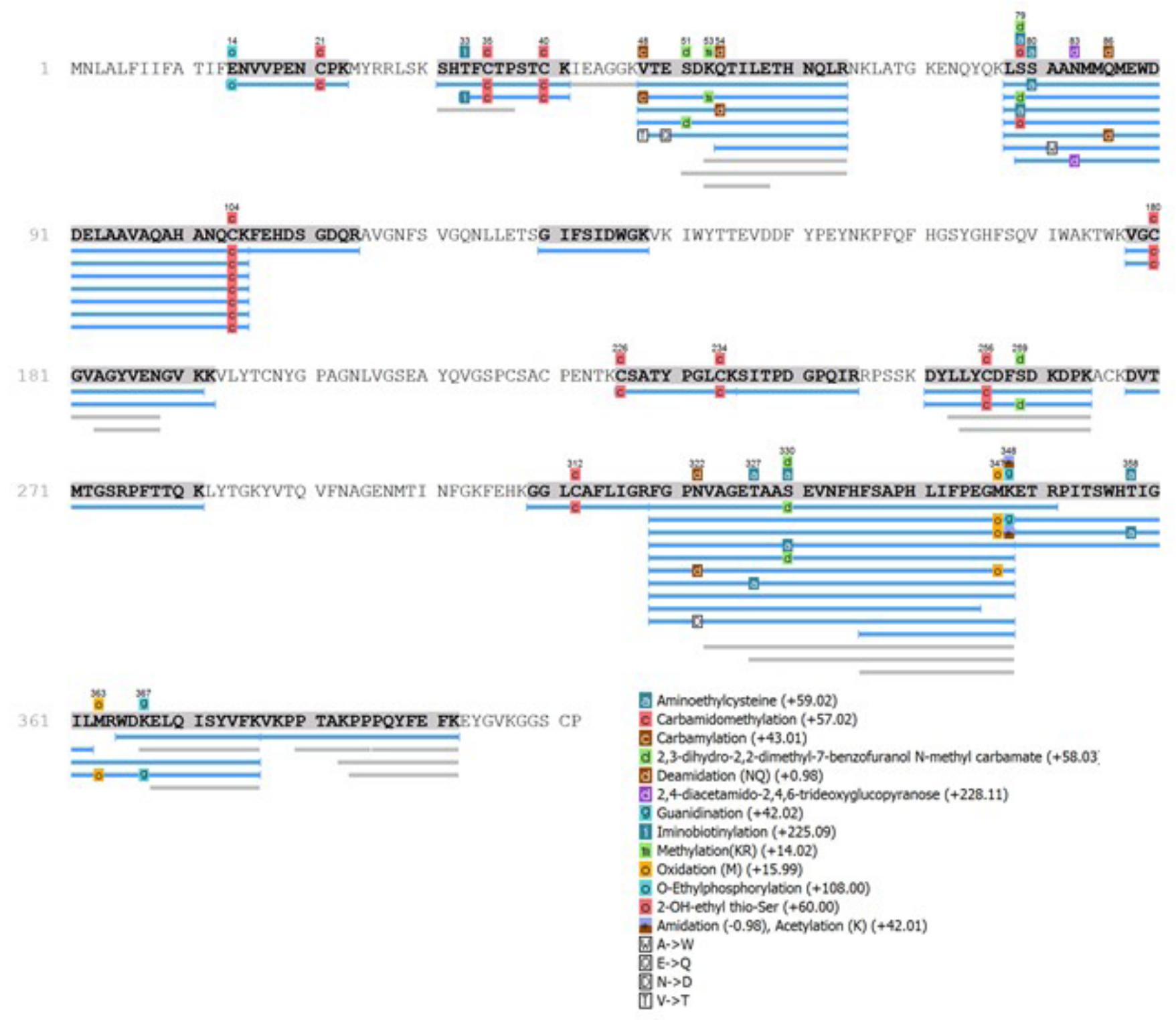

Figure 4. De novo sequencing of the CRISP identified in the Fraction I using the JAW07031.1 (putative cysteine-rich protein from Tityus serrulatus) as a template. 


\section{Discussion}

Although the omics approaches provide a holistic (although not exhaustive) view of the venom composition from the animals, there is a gap in the obtainment of these components directly from the venom, mainly due the low yield of purified toxins from milked venom. Therefore, a proteome fraction-directed or fraction subproteomes associated to shotgun proteomics can overcome this challenge.

In this study a preliminary fractionation of the Ts venom was performed using the cation exchange column CMC-52, as described by Arantes et al. [9] and Cerni et al. [5]. This fractionation is based on the electrostatic interaction between the sample components and the stationary phase at $\mathrm{pH}$ 7.8. The positively charged venom components interact with the negatively charged carboxymethyl groups of the resin and are eluted with the increase of the buffer concentration [9]. This Ts venom fractionation approach has some advantages, as the isolation of Ts1 (fraction XIII), corresponding to $16 \%$ of the soluble venom. In addition, enzymes, such as hyaluronidase and proteases, especially metalloproteinases, keep their activities under these chromatographic conditions [5].

The chromatographic fractionation of the Ts venom resulted in 18 fractions. Fraction $I$ is the first to be eluted, indicating that it is composed by proteins with character less basic than the other ones that are eluted with higher buffer concentrations. This fraction is rich in venom components, showing many protein bands with different molecular masses, in the Tricine-SDSPAGE. Additionally, Fraction I corresponds to approximately $30 \%$ of the Ts venom, being its major fraction.

The proteolytic activity assays of fraction I in the presence of inhibitors reveal the presence of both metalloproteases (inhibited by EDTA) and serine proteases (inhibited by PMSF). The existence of these proteases in Ts venom was reported before in omics studies of De Oliveira et al [32] that found 16 transcripts related to trypsin-like proteases and 1 sequence of trypsin-like serine protease in the T. serrulatus proteome. However, the chymotrypsin peptides found in our work represents the first evidence at protein level of the presence of this protease in the Ts venom.

The function of scorpion venom proteases has not been fully elucidated yet. These enzymes can cleave proteins at specific sites of the amino acid sequence and are classified according to the key amino acid at the catalytic site or according to the need of the metal ion to perform its function [34]. These enzymes are important for cellular metabolism, since they participate in the post-translational process of removal of the signal peptides, among others [35].

Proteinases can also act as toxins and are well characterized in the venoms of spiders and snakes. Concerning T. serrulatus venom, in 2010, a metalloproteinase called antarease, showed to be able to penetrate into intact tissues and cleaves vesicleassociated membrane proteins (VAMPs), which may alter vesicular transport and secretion mechanisms [36, 37]. Thus, antarease may be one of the compounds responsible for acute pancreatitis observed after envenoming with T. serrulatus
[36]. Recently, ten novel metalloproteinases sequences were predicted after analysis of the $T$. serrulatus venom gland transcriptome, called metaloserrulases [38].

Fraction I was also able to inhibit the ACE activity in vitro, and its proteome identified several components classified as hypotensive peptides. Some of these peptides are responsible for inhibiting the angiotensin converting enzyme, which converts angiotensin I to angiotensin II, a potent vasoconstrictor peptide. In addition, ACE also inactivates bradykinin, which is a vasodilator peptide [39]. These concomitant actions lead to a decrease in blood pressure, thus demonstrating the importance of these peptides as a possible molecular tool and/or therapeutic drug. Numerous studies reported already the presence of hypotensive peptides in animal's venom [27, 40, 41].

Several scorpion venom components act on the cardiovascular system. Among them natriuretic peptides [42], PAPE peptides [18], non-disulfide-bridged peptides [43], bradykininpotentiating peptides (BPPs) and hypotensins $[33,44]$ which are peptides that exhibits hypotensive properties. In our study, we found in Fraction I all these peptides, with exception of natriuretic peptide. In addition, we identified endothelinconverting enzyme, already found in the study of De Oliveira et al. [32]. Although endothelin is frequently considered as having a primarily cardiovascular role in the brain, the roles of this enzyme in the venom remains unclear [32, 45].

Another important result obtained from proteome of Fraction I was the identification of CRISP classes. This venom component has been already reported in other animal venom, such as snakes [46-48], spiders [49, 50] and scorpions [32, 51, 52]. The role of CRISPs in the venom remain unclear but they seem to interfere in the smooth-muscle contraction by inhibiting ion channels [53]. One CRISP identified in the transcriptome of T. serrulatus by De Oliveira [32] was sequenced in our study. These results show how subproteome can be effective to drive the researches in the isolation of components with biotechnological and therapeutic potential directly from the venom.

It is worth mentioning that some basic neurotoxins, such as Ts1, which are also found in fractions eluted at higher buffer concentrations, have been identified in Fraction I. This result shows that these neurotoxins may aggregate with other venom proteins, preventing their interactions with the resin during the chromatographic process, justifying their presence also in Fraction I. These phenomena contribute to increase the diversity of components present in this fraction, confirming our initial hypothesis that this fraction deserved to be better studied due to its diversity in bioactive components.

\section{Conclusion}

The study of the venom components has a remarkable importance in the toxinology field, which allows identifying molecules with biotechnological and therapeutic potentials. A fraction subproteome associated to biochemical characterization has an important role in the venom elucidation. Shotgun proteomics described at least 8 different venom component classes in Fraction 
I, among them proteases and hypotensive peptides, which were confirmed by enzymatic assays, revealing how complex is this fraction. Venom subproteomes may serve as a roadmap to obtain specific venom components in their native forms and therefore perform its preliminary characterization, promoting advances and biological discoveries to toxinology field.

\section{Availability of data and material}

The datasets used and/or analyzed during the current study are available from the corresponding author on reasonable request.

\section{Funding}

This study was supported by the National Council for Scientific and Technological Development (CNPq, scholarship to FGA n. 150037/2018-0; grants to ECA n. 303689/2013-7 and n. 449960/2014-5), the State of São Paulo Research Foundation (FAPESP, scholarship to FGA, n. 2013/26083-0 and n. 2011/123173; scholarship to HTL, n. 2014/22959-0 and n. 2014/07824-1; scholarship to CTC, n. 2013/26200-6 and n. 2015/17466-8; grants to ECA, n. 2011/23236-4, and 2012/14996-8). Moreover, this publication was supported in part by the Coordination for the Improvement of Higher Education Personnel (CAPES) through "Programa Editoração CAPES" - call No. 3/2016, grant No. 0722/2017, record No. 88881.142062/2017-01 and by the National Council for Scientific and Technological Development (CNPq) and Coordination for the Improvement of Higher Education Personnel (CAPES) through "Programa Editorial CNPq/CAPES" call No. 18/2018, grant No. 404770/2018-5.

\section{Competing interests}

The authors declare that there are no competing interests.

\section{Authors' contributions}

FGA and HLT performed the biochemical characterization and purification of Ts venom. Both authors contributed equally to this work. MD and HTL performed the shotgun proteomic experiments. FGA analyzed the proteomic data and wrote the manuscript. CTC, EDP and LQ supervised the mass spectrometry assays and data analysis. ECA and FGA are designer of the research, ECA searched for funding and supervised the experiments related to the venom fractionation and biochemical characterizations. All authors read, corrected and approved the final manuscript.

\section{Ethics approval and consent to participate}

Not applicable.

\section{Consent for publication}

Not applicable.

\section{Supplementary material}

The following online material is available for this article:
Additional file 1: Full list of proteins and peptides identified after proteomics analysis of Fraction I from T. serrulatus venom against the database. Only peptides with $-10 \lg \mathrm{P}>20$ were used to match the proteins in this study.

Additional file 2: Hypotensin-2 (P84190.1) found in the Fraction I, in which the de novo sequencing showed 210 de novo tags resulted from at least 22 amino acid residues mutations.

\section{References}

1. Pimenta AM, Stöcklin R, Favreau P, Bougis PE, Martin-Eauclaire MF Moving pieces in a proteomic puzzle: mass fingerprinting of toxic fractions from the venom of Tityus serrulatus (Scorpiones, Buthidae). Rapid Commun Mass Spectrom. 2001;15(17):1562-72.

2. Vasconcelos F, Lanchote VL, Bendhack LM, Giglio JR, Sampaio SV, Arantes $E C$. Effects of voltage-gated $\mathrm{Na}+$ channel toxins from Tityus serrulatus venom on rat arterial blood pressure and plasma catecholamines. Comp Biochem Physiol C Toxicol Pharmacol. 2005;141(1):85-92.

3. Cordeiro FA, Amorim FG, Anjolette FA, Arantes EC. Arachnids of medical importance in Brazil: main active compounds present in scorpion and spider venoms and tick saliva. J Venom Anim Toxins incl Trop Dis. 2015;21:24. doi: 10.1186/s40409-015-0028-5.

4. Lima PC, Bordon KCF, Pucca MB, Cerni FA, Zoccal KF, Faccioli LH, et al. Partial purification and functional characterization of Ts19 Frag-I, a novel toxin from Tityus serrulatus scorpion venom. J Venom Anim Toxins incl Trop Dis. 2015;21:49. doi: 10.1186/s40409-015-0051-6.

5. Cerni FA, Pucca MB, Peigneur S, Cremonez CM, Bordon KC, Tytgat J, et al. Electrophysiological characterization of Ts6 and Ts7, $\mathrm{K}^{+}$channel toxins isolated through an improved Tityus serrulatus venom purification procedure. Toxins (Basel). 2014;6(3):892-913.

6. Ortiz E, Rendón-Anaya M, Rego SC, Schwartz EF, Possani LD. Antareaselike $\mathrm{Zn}$-metalloproteases are ubiquitous in the venom of different scorpion genera. Biochim Biophys Acta. 2014;1840(6):1738-46.

7. Possani LD, Becerril B, Delepierre M, Tytgat J. Scorpion toxins specific for Na+-channels. Eur J Biochem. 1999;264(2):287-300.

8. Gazarian KG, Gazarian T, Hernández R, Possani LD. Immunology of scorpion toxins and perspectives for generation of anti-venom vaccines. Vaccine. 2005;23(26):3357-68.

9. Arantes EC, Prado WA, Sampaio SV, Giglio JR. A simplified procedure for the fractionation of Tityus serrulatus venom: isolation and partial characterization of TsTX-IV, a new neurotoxin. Toxicon. 1989;27(8):90716.

10. Pimenta AM, De Marco Almeida F, de Lima ME, Martin-Eauclaire MF, Bougis PE. Individual variability in Tityus serrulatus (Scorpiones, Buthidae) venom elicited by matrix-assisted laser desorption/ionization time-of-flight mass spectrometry. Rapid Commun Mass Spectrom. 2003;17(5):413-8.

11. Goudet C, Chi CW, Tytgat J. An overview of toxins and genes from the venom of the Asian scorpion Buthus martensi Karsch. Toxicon. 2002;40(9):1239-58.

12. Chen T, Walker B, Zhou M, Shaw C. Molecular cloning of a novel putative potassium channel-blocking neurotoxin from the venom of the North African scorpion, Androctonus amoreuxi. Peptides. 2005;26(5):731-6.

13. Barona J, Batista CV, Zamudio FZ, Gomez-Lagunas F, Wanke E, Otero $\mathrm{R}$, et al. Proteomic analysis of the venom and characterization of toxins specific for $\mathrm{Na}^{+}-$and $\mathrm{K}+$-channels from the Colombian scorpion Tityus pachyurus. Biochim Biophys Acta. 2006;1764:76-84.

14. Batista CV, D'Suze G, Gómez-Lagunas F, Zamudio FZ, Encarnación S, Sevcik $C$, et al. Proteomic analysis of Tityus discrepans scorpion venom and amino acid sequence of novel toxins. Proteomics. 2006;6(12):3718-27. 
15. Batista CV, Román-González SA, Salas-Castillo SP, Zamudio FZ, GómezLagunas F, Possani LD. Proteomic analysis of the venom from the scorpion Tityus stigmurus: biochemical and physiological comparison with other Tityus species. Comp Biochem Physiol C Toxicol Pharmacol. 2007;146(1-2):147-57.

16. Borges A, Rojas-Runjaic FJ. Tityus perijanensis González-Sponga (Scorpiones, Buthidae): molecular assessment of its geographical distribution and venom lethality of Venezuelan populations. Toxicon. 2007;50(7):1005-10.

17. Bringans S, Eriksen S, Kendrick T, Gopalakrishnakone P, Livk A, Lock R, et al. Proteomic analysis of the venom of Heterometrus longimanus (Asian black scorpion). Proteomics. 2008;8(5):1081-96.

18. Rates B, Ferraz KK, Borges MH, Richardson M, De Lima ME, Pimenta AM. Tityus serrulatus venom peptidomics: assessing venom peptide diversity. Toxicon. 2008;52(5):611-8.

19. Yates JR. Mass spectrometry. From genomics to proteomics. Trends Genet. 2000;16(1):5-8.

20. Quinton L, Demeure K, Dobson R, Gilles N, Gabelica V, De Pauw E. New method for characterizing highly disulfide-bridged peptides in complex mixtures: application to toxin identification from crude venoms. J Proteome Res. 2007;6(8):3216-23.

21. Degueldre M, Verdenaud M, Legarda G, Minambres R, Zuniga S, Leblanc $M$, et al. Diversity in sequences, post-translational modifications and expected pharmacological activities of toxins from four Conus species revealed by the combination of cutting-edge proteomics, transcriptomics and bioinformatics. Toxicon. 2017;130:116-25.

22. Schägger $\mathrm{H}$, von Jagow $\mathrm{G}$. Tricine-sodium dodecyl sulfate-polyacrylamide gel electrophoresis for the separation of proteins in the range from 1 to 100 kDa. Anal Biochem. 1987;166(2):368-79.

23. Gutiérrez JM, Avila C, Rojas E, Cerdas L. An alternative in vitro method for testing the potency of the polyvalent antivenom produced in Costa Rica. Toxicon. 1988;26(4):411-3.

24. Wang WJ, Shih CH, Huang TF. A novel P-I class metalloproteinase with broad substrate-cleaving activity, agkislysin, from Agkistrodon acutus venom. Biochem Biophys Res Commun. 2004;324(1):224-30.

25. Kishimoto M, Takahashi T. A spectrophotometric microplate assay for L-amino acid oxidase. Anal Biochem. 2001;298(1):136-9.

26. Li GH, Liu H, Shi YH, Le GW. Direct spectrophotometric measurement of angiotensin I-converting enzyme inhibitory activity for screening bioactive peptides. J Pharm Biomed Anal. 2005;37(2):219-24.

27. Pinheiro-Júnior EL, Boldrini-França J, de Campos Araújo LMP, SantosFilho NA, Bendhack LM, Cilli EM, et al. LmrBPP9: A synthetic bradykininpotentiating peptide from Lachesis muta rhombeata venom that inhibits the angiotensin-converting enzyme activity in vitro and reduces the blood pressure of hypertensive rats. Peptides. 2018;102:1-7.

28. Pukrittayakamee S, Warrell DA, Desakorn V, McMichael AJ, White NJ, Bunnag D. The hyaluronidase activities of some Southeast Asian snake venoms. Toxicon. 1988;26(7):629-37.

29. Amorim FG, Boldrini-França J, de Castro Figueiredo Bordon K, Cardoso IA, De Pauw E, Quinton L, et al. Heterologous expression of rTsHyal-1: the first recombinant hyaluronidase of scorpion venom produced in Pichia pastoris system. Appl Microbiol Biotechnol. 2018;102(7):3145-58.

30. Ma B, Zhang K, Hendrie C, Liang C, Li M, Doherty-Kirby A, et al. PEAKS: powerful software for peptide de novo sequencing by tandem mass spectrometry. Rapid Commun Mass Spectrom. 2003;17(20):2337-42.

31. Zainal Abidin SA, Rajadurai P, Chowdhury ME, Ahmad Rusmili MR, Othman I, Naidu R. Proteomic characterization and comparison of Malaysian Tropidolaemus wagleri and Cryptelytrops purpureomaculatus venom using shotgun-proteomics. Toxins (Basel). 2016;8(10):pii: E299.

32. de Oliveira UC, Nishiyama MYJr, Dos Santos MBV, Santos-da-Silva AP, Chalkidis HM, Souza-Imberg A, et al. Proteomic endorsed transcriptomic profiles of venom glands from Tityus obscurus and T. serrulatus scorpions. PLoS One. 2018;13(3):e0193739.

33. Verano-Braga T, Figueiredo-Rezende F, Melo MN, Lautner RQ, Gomes ER, Mata-Machado LT, et al. Structure-function studies of Tityus serrulatus Hypotensin-I (TsHpt-I): A new agonist of $B(2)$ kinin receptor. Toxicon. 2010;56(7):1162-71.

34. Mótyán JA, Tóth F, Tőzsér J. Research applications of proteolytic enzymes in molecular biology. Biomolecules. 2013;3(4):923-42.

35. Duan $G$, Walther D. The roles of post-translational modifications in the context of protein interaction networks. PLoS Comput Biol. 2015;11(2):e1004049.

36. Fletcher PLJr, Fletcher MD, Weninger K, Anderson TE, Martin BM. Vesicle-associated membrane protein (VAMP) cleavage by a new metalloprotease from the Brazilian scorpion Tityus serrulatus. J Biol Chem. 2010;285(10):7405-16.

37. Venancio EJ, Portaro FC, Kuniyoshi AK, Carvalho DC, Pidde-Queiroz G, Tambourgi DV. Enzymatic properties of venoms from Brazilian scorpions of Tityus genus and the neutralisation potential of therapeutical antivenoms. Toxicon. 2013;69:180-90.

38. Carmo AO, Oliveira-Mendes BB, Horta CC, Magalhães BF, Dantas $A E$, Chaves LM, et al. Molecular and functional characterization of metalloserrulases, new metalloproteases from the Tityus serrulatus venom gland. Toxicon. 2014;90:45-55.

39. Wu J, Aluko RE, Nakai S. Structural requirements of Angiotensin I-converting enzyme inhibitory peptides: quantitative structureactivity relationship study of di- and tripeptides. J Agric Food Chem. 2006;54(3):732-8.

40. Ferreira LA, Galle A, Raida M, Schrader M, Lebrun I, Habermehl G. Isolation: analysis and properties of three bradykinin-potentiating peptides (BPP-II, BPP-III, and BPP-V) from Bothrops neuwiedi venom. J Protein Chem. 1998;17(3):285-9.

41. Higuchi S, Murayama N, Saguchi K, Ohi H, Fujita Y, da Silva NJ, et al. A novel peptide from the ACEI/BPP-CNP precursor in the venom of Crotalus durissus collilineatus. Comp Biochem Physiol C Toxicol Pharmacol. 2006;144(2):107-21.

42. Alves RS, Ximenes RM, Jorge AR, Nascimento NR, Martins RD, Rabello $\mathrm{MM}$, et al. Isolation, homology modeling and renal effects of a C-type natriuretic peptide from the venom of the Brazilian yellow scorpion (Tityus serrulatus). Toxicon. 2013;74:19-26.

43. Pucca MB, Cerni FA, Pinheiro-Junior EL, Zoccal KF, Bordon KCF, Amorim FG, et al. Non-disulfide-bridged peptides from Tityus serrulatus venom: Evidence for proline-free ACE-inhibitors. Peptides. 2016;82:44-51.

44. Machado RJ, Junior LG, Monteiro NK, Silva-Júnior AA, Portaro FC, Barbosa EG, et al. Homology modeling, vasorelaxant and bradykininpotentiating activities of a novel hypotensin found in the scorpion venom from Tityus stigmurus. Toxicon. 2015;101:11-8.

45. Sluck JM, Lin RC, Katolik LI, Jeng AY, Lehmann JC. Endothelin converting enzyme-1-, endothelin-1-, and endothelin-3-like immunoreactivity in the rat brain. Neuroscience. 1999;91(4):1483-97.

46. Amorim FG, Morandi-Filho R, Fujimura PT, Ueira-Vieira C, Sampaio $\mathrm{SV}$. New findings from the first transcriptome of the Bothrops moojeni snake venom gland. Toxicon. 2017;140:105-17.

47. Lodovicho ME, Costa TR, Bernardes CP, Menaldo DL, Zoccal KF, Carone SE, et al. Investigating possible biological targets of $\mathrm{Bj}-\mathrm{CRP}$, the first cysteine-rich secretory protein (CRISP) isolated from Bothrops jararaca snake venom. Toxicol Lett. 2017;265:156-69.

48. Adade CM, Carvalho AL, Tomaz MA, Costa TF, Godinho JL, Melo PA, et al. Crovirin, a snake venom cysteine-rich secretory protein (CRISP) with promising activity against Trypanosomes and Leishmania. PLoS Negl Trop Dis. 2014;8(10):e3252.

49. Kuzmenkov AI, Fedorova IM, Vassilevski AA, Grishin EV. Cysteinerich toxins from Lachesana tarabaevi spider venom with amphiphilic C-terminal segments. Biochim Biophys Acta. 2013;1828(2):724-31.

50. Clement H, Flores V, Diego-Garcia E, Corrales-Garcia L, Villegas E, Corzo G. A comparison between the recombinant expression and chemical synthesis of a short cysteine-rich insecticidal spider peptide. J Venom Anim Toxins incl Trop Dis. 2015;21:19. doi: 10.1186/s40409. 015-0018-7. 
51. Santibáñez-López CE, Ontano AZ, Harvey MS, Sharma PP. Transcriptomic analysis of pseudoscorpion venom reveals a unique cocktail dominated by enzymes and protease inhibitors. Toxins (Basel). 2018;10(5):pii: E207.

52. Yang Y, Zeng XC, Zhang L, Nie Y, Shi W, Liu Y. Androcin, a novel type of cysteine-rich venom peptide from Androctonus bicolor, induces akinesia and anxiety-like symptoms in mice. IUBMB Life. 2014;66(4):277-85.
53. Yamazaki Y, Hyodo F, Morita T. Wide distribution of cysteine-rich secretory proteins in snake venoms: isolation and cloning of novel snake venom cysteine-rich secretory proteins. Arch Biochem Biophys. 2003;412(1):133-41. 